\title{
The Relationship of Nonlinguistic Visual Processing Capacity, Speed, and Vocabulary Ability in Children with Specific Language Impairment
}

\author{
Dongsun Yim, Yoonhee Yang \\ Department of Communication Disorders, Ewha Womans University, Seoul, Korea
}

Correspondence: Dongsun Yim, PhD Department of Communication Disorders, Ewha Womans University, 52 Ewhayeodae-gil, Seodamun-gu, Seoul 03760, Korea

Tel: $+82-2-3277-6720$

Fax: +82-2-3277-2122

E-mail: sunyim@ewha.ac.kr

Received: April 10, 2018

Revised: May 20, 2018

Accepted: June 1, 2018
Objectives: The purpose of this study was to investigate whether children with specific language impairment (SLI) show their deficits when performing nonlinguistic processing tasks, and whether the relationship of nonlinguistic information processing tasks (processing capacity/speed) and language (receptive/expressive vocabulary) differ in children with and without language impairment. Methods: Sixty-four children $(S L I=32, N L=32)$ aged 4-8 years participated in this study. This study used matrix forward (Matrix_f) and backward (Matrix_b) for examining nonlinguistic processing capacity, and a visual number search to examine nonlinguistic processing speed. Results: SLI group had significantly lower performance in Matrix_b, VNS_Acc(C5), and slower in VNS_RT(C1) expect for Matrix_ $\mathrm{f}$. In addition, there was a significant correlation between language and nonlinguistic information processing (Matrix_b, VNS_C1C4_Acc) in NL group, but there was no significant correlation in the SLI group. Conclusion: Children with SLI store and retrieve visual information sequentially similarly to their NL peers, but they have difficulty remembering the information in reverse. In addition, the relationship between nonlinguistic processing ability and vocabulary was not significant in SLI group. These results indicate that children with SLI need various opportunities to improve their visual processing capacity and speed because of a weak connection between processing and vocabulary.

Keywords: Nonlinguistic visual tasks, Processing capacity, Processing speed, Specific language impairment 일반인지처리이론(general cognitive processing theory)은 정보 처리(information processing), 즉 언어적 또는 비언어적 정보를 처 리하는 용량 및 처리속도가 아동의 언어습득 및 발달에 중요한 역 할을 한다는 신경인지이론(neurocognitive theory)이다. 언어는 일 종의 언어적 정보(linguistic information)이며 이를 처리하는 데는 정보처리 속도와 정보저장 용량이 대부분의 역할을 하는 것이며 추후 언어성과를 예측하는 데에 유용하다고 이미 많은 학자들이 주장해왔다(Pisoni, Kronenberger, Roman, \& Geers, 2011). 그러므 로 언어에 어려움을 겪는 아동을 정보처리이론에 입각하여 설명하 면, 처리용량의 제한은 언어능력에 부정적 영향을 미칠 수 있으며 (Leonard et al., 2007) 처리속도의 제한 역시 언어습득을 지연시키 는 데에 매우 결정적인 역할을 한다. Kail과 Salthouse (1994)는 정
보처리에 중요한 요소를 세 가지로 설명한다. 첫째, 공간(space)은 얼마나 많은 정보를 기억하고 저장할 수 있는가를 결정하고, 둘째, 시간(time)은 정보를 얼마나 빨리 처리할 수 있는지를 설명해주며, 마지막으로 효율성(energy)은 얼마나 많은 정보를 빠른 시간 내에 처리할 수 있는지를 말해준다. 이 세 가지로 수많은 처리 과제들의 특성에 대해 설명할 수 있는데, 많은 시간이 걸리거나 많은 용량을 필요로 하는 과제는 그 과제의 난이도가 더 어려운 것으로 설명된 다. 그 중에서도 어떤 과제는 처리용량이 더 비중이 크고 중요한 역 할을 하는 과제가 있을 수 있는 반면(예: 매트릭스, 숫자 기억하기, 비단어 따라말하기) 어떤 과제는 처리속도, 즉 시간이 더 중요한 역 할을 하는 과제가 있을 수 있다(예: 빨리 숫자찾기, 빠르게 색깔이 름대기) 
처리용량은 공간과 에너지 측면에서 설명되며, 흔히 작업기억이 라 불리기도 한다. 만약, 처리용량에 제한이 있다면 정보를 저장하 고 조작하는 데에 어려움을 보이게 된다(Leonard et al., 2007). 처리 속도는 입력되는 정보를 인지적으로 처리할 수 있는 속도를 의미하 며, 빠른 처리속도는 작업기억 공간에서 더 많은 정보들을 수용할 수 있게 하여 효율성을 증대시킨다(Bayliss, Jarrold, Baddeley, Gunn, \& Leigh, 2005). 즉, 처리속도는 입력된 정보가 사라지기 전 또는 새 롭게 들어오는 정보가 간섭하기 전에 정보를 처리할 수 있는 능력 을 말한다(Miller \& Vernon, 1996). 처리속도는 아동의 연령이 증가 함에 따라 빨라지며, 효율성이 증가하고, 작업기억을 확장시킨다 (Bayliss et al., 2005). 이처럼 처리용량과 처리속도는 매우 유기적으 로 연결되어 있다고도 볼 수 있지만, 최근 밝혀진 연구에 의하면, 처 리속도의 제한과 작업기억의 제한의 개념은 서로 기능적으로 분리 되어 있으며, 매우 독립적인 것으로 언급되고 있다(Leonard et al., 2007). 언어는 매우 빠른 속도로 아동에게 전달이 되기 때문에 아 동이 이미 알고 있는 어휘라 할지라도 그 어휘를 더 빨리 처리(예: 어 휘집에 접근 및 인출하는 과정)하는 아동이 더 느리게 처리하는 아 동보다 어휘 습득력이 현저하게 뛰어나다는 연구결과들이 많다 (Fernald \& Marchman, 2012; Fernald, Perfors, \& Marchman, 2006). Marchman과 Fernald (2008)는 25개월 아기의 구어 인식 속도가 8 세의 언어능력과 관련 있다고 보고했으며, 25 개월 때의 더 빠른 처 리속도가 말 늦은 아동의 언어문제를 해결할 수 있는지도 예측해 줄 수 있다고 보았다(Fernald \& Marchman, 2012). Poll 등(2013)은 과업 난이도가 증가했을 때, 처리속도가 작업기억 측정과는 별개 로 부가적인 독특한 변수로 언어수행을 설명해준다고 언급하였다. 특히, 초기 처리속도, 작업기억, 그리고 언어발달 간 상호관계를 보 고한 선행연구들을 통해 초기 처리속도 및 언어기술은 광범위한 인지기능의 근간을 이루고 있음을 알 수 있다(Marchman \& Fernald, 2008; Newbury, Klee, Stokes, \& Moran, 2016).

단순언어장애(specific language impairment, SLI) 아동들은 언 어능력의 결함뿐만 아니라 비언어적 정보처리용량 및 처리속도에 서 어려움을 나타낸다(Johnston \& Ellis Weismer, 1983; Kohnert \& Windsor, 2004; Leonard et al., 2007; Windsor, Kohnert, Loxtercamp, \& Kan, 2008). 심지어 단순언어장애 아동들은 최소한의 처 리용량이 요구되더라도 이들의 처리속도는 기대되는 것보다 훨씬 느리게 나타난다(Weber-Fox et al., 2005). Johnston과 Ellis Weismer (1983)는 단순언어장애 아동이 비언어 시각 과제인 심적 회전 (mental rotation)과제 수행 시 또래 일반아동(normal language children, NL)만큼 정확하게 수행했으나, 더 느린 속도를 보였다고 보고하였다. Kohnert와 Windsor (2004)는 단순언어장애 아동을
확인하기 위한 비언어 탐지 과제의 효용성을 탐색하였는데, 단순언 어장애 아동이 시각적 탐지 선택 과제수행 시 또래 일반아동보다 느린 수행을 보였다. 이처럼 단순언어장애 아동들에게서 비언어적 정보처리 속도는 느리게 나타나는 경향이 있다. 그러나, 단순언어 장애 및 일반아동 집단 간 처리속도의 차이는 연령에 따라 통계적 으로 유의함이 검증되지 않거나 작게 나타나기도 하며 과제에 사 용된 자극이 언어 또는 비언어적인지, 단순 또는 복잡한 과제인지 에 따라 차이가 나타날 수 있다(Kohnert \& Windsor, 2004; Miller, Kail, Leonard, \& Tomblin, 2001; Windsor et al., 2008). 그럼에도 불구하고, 언어와 인지적 능력이 서로 밀접한 관련을 맺고 있음이 수많은 연구들을 통해 보고된 바 있으며, 언어능력은 독립적이기보 다는 다양한 인지영역들과 함께 발달하는 것으로 나타난다(Fernald \& Marchman, 2012; Marchman \& Fernald, 2008). 이로 인해 언어평가 및 중재 시에도 어휘, 문법능력뿐 아니라 그 기저를 살펴 보는 것의 중요성이 부각되고 있다.

한편, Park, Mainela-Arnold와 Miller (2015)는 비언어 처리속도 가 언어장애 정도를 설명해줄 수 있다고 보고했으며, 특히, 3학년 아동의 경우 문법성 판단과 같은 언어적 과제가 단순언어장애 유 무를 판별하는 데 가장 적합하였으나, 더 연령이 높은 8 학년 아동 에게서 음운 과제와 같은 언어적 과제와 더불어 비언어적인 처리속 도가 단순언어장애 유무를 판단하는 데 유의한 기여를 한 것으로 나타났다. 또한, 임상적 지표로서 느린 처리속도는 단순언어장애가 없는지 여부 보다는 단순언어장애가 있는지를 더 잘 예측해준다고 하였다. 이처럼 비언어적 처리속도는 언어능력과 연결고리가 있는 것으로 보이며, 느린 처리속도는 수용 및 표현언어, 그리고 어휘학 습에 직접적으로 부정적인 영향을 미칠 수 있다(Lahey, Edwards, \& Munson, 2001; Park et al., 2015). Leonard 등(2007) 역시 14세 아 동의 비언어 및 언어 처리속도가 언어능력을 예측해준다고 보고하 였다. 반면, Lahey 등(2001)은 더 어린 아동인 만 6세 아동을 대상 으로 하였을 때 반응속도와 어휘처리와의 관계가 나타나지 않는다 고 보고하였다. 이처럼 처리 결함은 연령이 증가할수록 더욱 뚜렷 하게 나타나는 것으로 보인다. 이는 일반아동들은 처리속도 발달 이 어느 시점에서 정상에 도달하는 반면, 단순언어장애 아동들은 처리속도 발달에서 지속적인 지연을 보여 연령이 증가할수록 격차 가 커질 수 있기 때문이다(Kail, 1986).

위와 같이 단순언어장애 아동들의 비언어 처리능력을 측정하기 위한 것으로 크게 비언어 처리용량과 비언어 처리속도를 측정하는 과제로 나누어 살펴볼 수 있다. 특히 비언어 처리기반과제는 이전에 습득한 지식의 역할 또는 경험이 덜 강조되어 선행 언어지식과 능 력이 과제수행에 미치는 역할을 최소화할 수 있는 장점을 지닌다 
(Campbell, Dollaghan, Needleman, \& Janosky, 1997). 비언어 처리 용량을 측정하기 위한 과제의 예로는 '매트릭스(matrix)'가 있으며, 매트릭스는 시공간적인 작업기억 용량을 측정하는 과제로 $3 \times 3$ 매 트릭스 위에 나타나는 불빛을 보고 순차적으로 또는 거꾸로 기억 하여 비언어적인 방법으로(예: 손가락으로 가리키기) 수행한다. 특 히, 단순언어장애 아동이 비언어적 작업기억능력에서 낮은 정확도 및 느린 속도를 보인다는 연구결과에 근거하여 비언어적 처리용량 과제가 단순언어장애 아동의 과제 수행부담을 줄여주면서도 이들 의 어려움을 확인하기에 효과적인 것으로 보기도 하였다(Bishop,

2006; Conti-Ramsden \& Durkin, 2012; Thomas, Reeve, Fredrickson, \& Maruff, 2011). 한편, 비언어 처리속도를 측정하기 위한 과제 로는 '시각적 숫자찾기 과제(visual number search task)'가 있다. 이 과제는 비언어적인 인지 과제로, Kail, Pellegrino와 Carter (1980)와 Leonard 등(2007)의 연구 등에서 사용되었는데 아이들은 목표자 극을 보고, 일련의 5 개 그림을 왼쪽에서 오른쪽으로 훝은 후 목표 자극이 있으면 초록색 키를, 목표그림이 없으면 빨간색 키를 누른 다. 이러한 과제들은 자극 배열의 위치에 따라 조건을 나누어 살펴 보는 것이 특징이다. 만약 목표자극이 제시된 일련의 자극 배열 속 에서 체계적으로 가깝게 배치되면 반응속도는 빠를 것으로 기대되 고, 멀게 배치되면 반응속도는 느릴 것으로 기대된다. Miller 등(2001) 은 시각적 찾기 과제를 사용하여 단순언어장애 아동이 그들의 또 래 일반아동들과 비슷한 정확도로 수행했으나 더 느린 경향이 있 었다고 보고하였다.

국내에서도 단순언어장애 아동들을 대상으로 비언어 처리능력 을 살펴본 연구들이 있었는데, Keum, Kim과 Lee (2010)는 4-6세 단순언어장애 아동들이 생활연령을 일치시킨 일반아동과 비교했 을 때 비언어과제 수행에서 부족함을 보인다고 보고하였으며, 단순 언어장애 아동들의 낮은 정확도와 느린 반응속도가 많은 단순언어 장애 아동들의 특징이 될 수 있을 것으로 보았다. 또한, Yim, Yang과 $\operatorname{Kim}$ (2015)의 연구에서는 4-8세의 연령대의 아동을 대상으로 하였 을 때 단순언어장애 아동의 수용어휘력은 시각 작업기억이 가장 잘 예측해주는 반면, 또래 일반아동은 청각 작업기억이 수용어휘 력을 가장 잘 예측해주는 것으로 나타나 상반된 특징을 보였다. 한 편, Yim, Yang, Jo, Lee와 Seong (2015)의 연구에서는 학령전기 단 순언어장애 아동에게 상대적으로 비언어성 작업기억능력이 잔존 하여 일반아동과 수행 차이를 보이지 않는다고 보고하였다. 이처럼 단순언어장애 아동들의 비언어 처리능력은 연구의 성격에 따라 다 르게 나타나고 있으나, 비언어 처리능력이 단순언어장애 아동들에 게는 특히 선행 언어지식의 영향력을 최소화할 수 있는 가능성이 존재하는 만큼, 이 능력을 처리용량과 처리속도로 각각 세부적으
로 나누고, 이와 언어 또는 어휘능력이 어떤 관련을 보이는지 살펴 보는 것은 의의가 있다.

따라서 본 연구에서는 언어능력이 또래에 비해 낮은 아동들과 생활연령을 일치시킨 일반아동을 대상으로 비언어적 정보처리 과 제 수행력을 처리용량과 처리속도로 나누어 비교 분석해보고자 한다. 한편 비언어적 정보처리능력이 아동 및 청소년의 읽기 및 언 어능력의 구성 요소와 유의한 상관관계가 있음을 밝힌 많은 연구 들이 있는데(Hood \& Conlon, 2004; Shanahan et al., 2006; Wright, Bowen, \& Zecker, 2000), 아동기의 언어발달지연이 추후 언어학습 능력 및 읽기능력 발달에 제약이 될 수 있음을 고려할 때, 아동기 단순언어장애 아동을 대상으로 비언어적 정보처리 과제의 수행력 을 면밀히 검토해 볼 필요가 있다. 이에 대한 세부적인 연구질문은 다음과같다.

첫째, 단순언어장애 및 또래 일반아동의 비언어 처리용량 및 처 리속도는 집단 간 차이가 유의하게 나타나는가?

둘째, 단순언어장애 및 또래 일반아동 집단 각각에서 비언어 처 리용량, 처리속도, 그리고 언어능력 간 유의한 상관관계가 다른 양 상으로 나타나는가?

셋째, 단순언어장애 및 또래 일반아동 집단 각각에서 비언어 처 리용량 및 처리속도는 언어능력을 유의하게 설명해주는가?

\section{연구방법}

\section{연구대상}

본 연구는 서울 및 수도권에 거주하는 만 5-8세의 단순언어장애 아동 32 명(남아 19 , 여아 13) 및 그와 생활연령을 일치시킨 일반아 동 32 명(남아 14 , 여아 18), 총 64명을 대상으로 하였다. 연령분포는 5세 22명, 6세 37명, 7세 3명, 8세 2명이었다. 연령별 수용어휘 점수 의 평균은 5세 55.64 점(SD=12.22), 6세 64.24점(SD=13.10), 7세 77.33점(SD = 17.04), 8세 84.00점(SD=22.63)이었고, 표현어휘점수 는 5세 63.23점(SD=15.79), 6세 63.23점(SD=71.97), 7세 74.67점 $(\mathrm{SD}=12.50), 8$ 세 84.50점(SD=7.78)이었다.

모든 대상자는 (1) 주양육자 및 담임교사에 의해 정서 및 사회적 상호작용 등의 문제가 없고, 감각(시각 및 청각) 및 신경학적 결함의 이력이 없는 것으로 보고되고, (2) 카우프만 아동용 지능검사(Korean Kaufman Assessment Battery for Children, K-ABC; Moon \& Byun, 2003)의 비언어성 지능지수가 85 (-1 SD) 이상인 아동으로 선 정하였다. 단순언어장애 아동은 Leonard (1998)의 단순언어장애 진단 기준을 근거로 선별하였으며, 부모보고를 통해 언어능력이 부 족하다고 보고되고, 표준화 검사인 수용 및 표현어휘력검사(Re- 
Table 1. Participants' characteristics

\begin{tabular}{lccc}
\hline & $\mathrm{NL}(\mathrm{N}=32)$ & $\mathrm{SLI}(\mathrm{N}=32)$ & $F$ \\
\hline Age (mo) & $73.63(6.90)$ & $72.41(6.90)$ & .483 \\
Nonverbal IO $^{\text {a }}$ & $111.53(9.91)$ & $105.13(12.15)$ & 1.534 \\
Receptive vocabulary $^{b}$ & $72.50(11.60)$ & $52.53(9.14)$ & $58.53^{* *}$ \\
Expressive vocabulary $^{b}$ & $78.50(9.81)$ & $60.47(11.73)$ & $44.47^{* *}$
\end{tabular}

Values are presented as mean (SD).

$\mathrm{NL}=$ normal language children; $\mathrm{SLI}=$ children with specific language impairment. aKorean Kaufman Assessment Battery for Children (Moon \& Byun, 2003); ' $R e c e p-$ tive \& Expressive Vocabulary Test (Kim, Hong, Kim, Jang, \& Lee, 2009). ${ }^{* *} p<.01$.

ceptive \& Expressive Vocabulary Test, REVT; Kim, Hong, Kim, Jang, \& Lee, 2009) 결과 수용어휘력 또는 표현어휘력이 또래 집단 대비 $10 \%$ ile 미만인 아동들로 하였다. 일반아동은 부모보고 체크 리스트를 통해 언어능력 및 수용어휘력과 표현어휘력이 모두 정상 발달 범주인 아동들로서, 각 집단의 생활연령, 비언어성 지능지수, 부모보고, 수용어휘력 및 표현어휘력 점수의 평균 및 표준편차를 Table 1에 제시하였다. 일원배치분산분석(one-way ANOVA)을 실 시한 결과, 두 집단의 생활연령과 비언어성 지능지수에는 통계적으 로 유의한 차이가 없었으며, 수용어휘력 점수 $\left(F_{(1,62)}=58.53, p<.01\right)$ 및 표현어휘력 점수 $\left(F_{(1,62)}=44.47, p<.01\right)$ 에만 유의한 차이가 있는 것으로 나타났다.

\section{연구도구}

비언어적 처리용량 - 매트릭스(matrix) 과제

본 과제는 시공간 작업기억을 측정하기 위해 개발된 선행연구 (Yim, Kim, \& Yang, 2015)의 과제를 사용하였다. 연구 대상자는 컴 퓨터 화면에 제시된 $3 \times 3$ 검정색 매트릭스에 $500 \mathrm{~ms}$ 간격으로 주 황색의 불이 점등되면, 그 순서를 기억했다가 반응하도록 한다. 9 개 의 칸에 점등되는 순서를 그대로 회상하는 순차 과제와 역순으로 회상하는 과제 두 가지의 방식으로 모두 실시하였으며, 과제 간 간 섭효과를 배제하기 위하여 매트릭스 순차 과제와 역순 과제는 실험 의 맨 처음과 맨 마지막으로 배치하였다. 역순 과제의 경우 아동이 '거꾸로'의 의미를 정확히 이해하는지 여부를 판단한 후 실시하였 다. 9 개의 매트릭스 가운데 점등되는 칸의 수는 2 개(1단계)부터 5 개 (4단계)까지 점차 늘어나며, 1 단계와 2단계가 각각 4 문항씩, 3 단계 와 4 단계가 각각 5 문항씩으로, 총 18 문항으로 구성되어 있다. 모든 반응은 구어가 아닌 손가락으로 가리키기 방식으로 답하도록 지시 하였으며, 아동이 정반응한 문항에 각 1점씩 부과하여 총점을 계산 하였으며, 백분율로 정반응률을 산출하였다.

\section{비언어적 처리속도 - 시각적 숫자찾기(visual number search) 과제}

본 과제는 비언어적 처리능력을 측정하기 위하여 선행연구(Windsor et al., 2008)에서 사용된 과제를 수정하여 사용하였다. 연구대 상자는 컴퓨터 화면에 목표 숫자 하나와 동시에 12 개의 숫자목록 이 나열되면, 목표 숫자가 12 개의 보기 숫자목록 중에서 있는지 없 는지를 판단하여 컴퓨터 키보드를 누르게 된다. 목표 숫자는 컴퓨 터 화면의 가장 왼쪽에 제시되며, 목표 숫자의 오른쪽으로 12 개의 숫자들이 목표 숫자와 동시에 나열되어 제시된다. 연구대상자는 컴 퓨터 화면에 제시된 숫자들을 왼쪽부터 오른쪽까지 시각적으로 탐 색하면서 12 개의 보기 숫자들 가운데 목표 숫자를 찾았을 때에는 키보드에 표시된 'O' 버튼을, 목표 숫자가 없을 때에는 키보드에 표 시된 'X' 버튼을 최대한 빨리 누르도록 연구자에게 지시 받는다. 모 든 자극들은 1 부터 19 사이의 숫자들로 구성하였으며, 12 개의 보기 숫자목록을 동등하게 4 개의 블록으로 나누어 목표 숫자가 첫 번째 블록인 앞의 3 개 중에 있을 경우인 조건 1 , 두 번째 블록에 있을 경 우인 조건 2, 세 번째 블록에 있을 경우인 조건 3 , 네 번째 블록에 있 을 경우인 조건 4 로 나누어 15 문항씩 배치하였다. 그리고 목표 숫자 가 12 개의 보기 숫자목록에 없는 경우인 조건 5 도 15 문항 배치하 여 총 문항수는 75 개로 구성하였다. 보기 숫자목록에서 모든 숫자 들은 중복 없이 한 번씩만 나열되며, 75 개의 문항은 조건에 상관없 이 무작위로 배치되어 모든 아동들에게 동일하게 제시되었다. 과제 실시 전 연구대상 아동들이 1 부터 19 까지의 숫자를 읽을 수 있는지 확인 후 숫자를 읽지 못하는 아동들은 연구대상에서 제외하였으 며, '책을 읽을 때처럼' 숫자를 왼쪽부터 오른쪽까지 순차적으로 탐 색하도록 지시하였다. 본 과제는 E-Prime으로 제작하여 정오 여부 와 반응시간을 측정할 수 있도록 하였다. 아동이 정반응한 문항에 각 1 점씩을 부과하여 총점을 계산하였으며, 백분율로 정반응률을 산출하여 분석하였다. 본 과제에서 사용된 조건에 따른 자극물을 Figure 1에 제시하였다.

\section{자료분석 및 결과처리}

본 연구는 집단 간 비언어적 처리용량 과제의 수행력 차이를 분 석하기 위하여 매트릭스 순행 및 역행 과제에 대해 각각 일원분산 분석(one-way ANOVA)을 실시하였으며, 비언어적 처리속도 과제 의 수행력 차이를 분석하기 위하여 시각적 숫자찾기 과제의 정확도 및 반응속도에 대해 집단 및 조건을 독립변수로 하는 반복측정 이 원분산분석(repeated two-way ANOVA)과 사후분석을 위한 일원 분산분석(one-way ANOVA)을 실시하였다. 정확도는 맞으면 1점, 틀리면 0점을 부여하여 백분율(\%) 점수를 산출하였고, 반응속도 

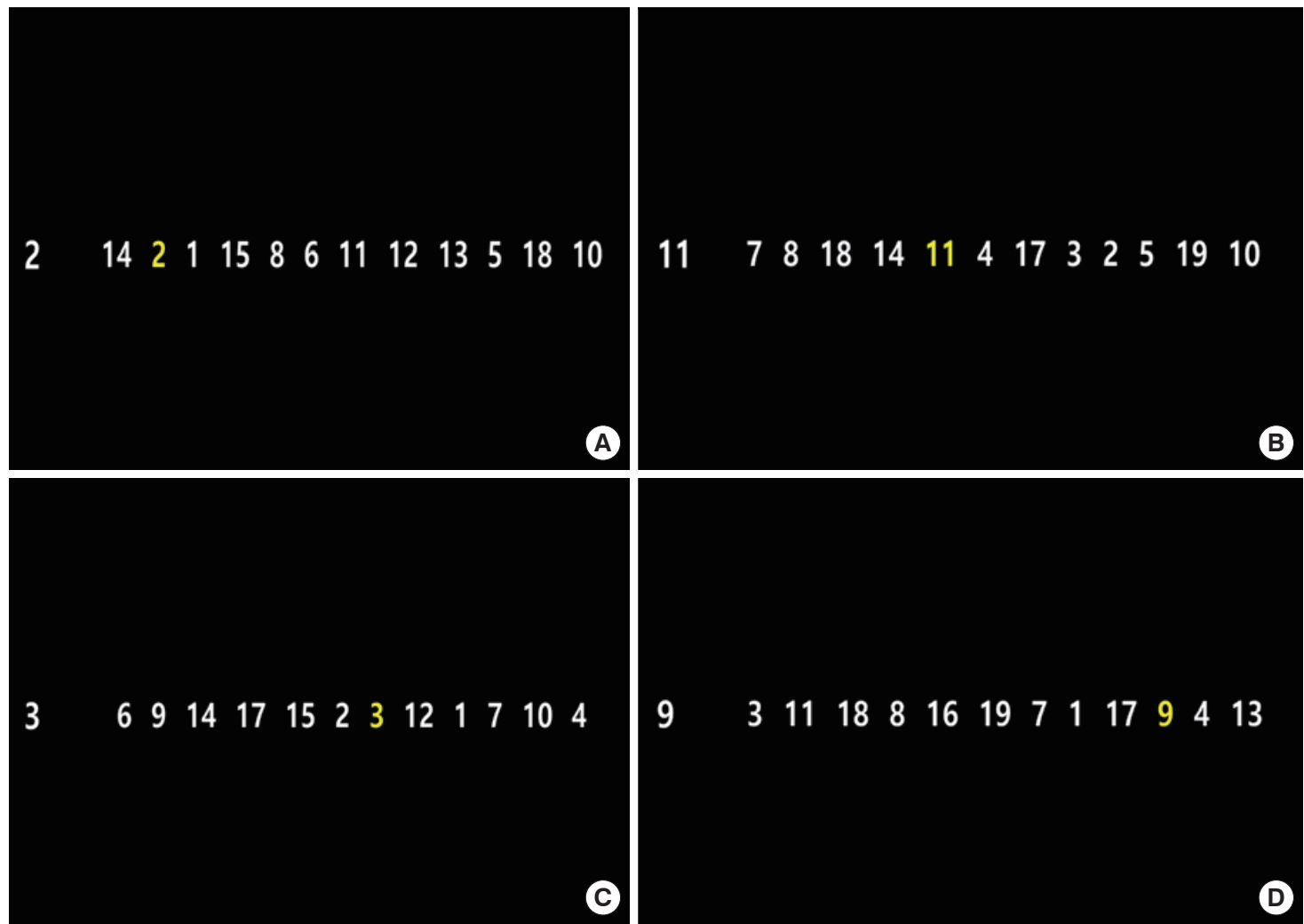

Figure 1. Examples of visual number search task: (A) condition 1, (B) condition 2, (C) condition 3, and (D) condition 4.

는 연구대상자가 정반응한 문항만을 분석에 포함하였으며, 반응시 간이 $100 \mathrm{~ms}$ 미만이거나 평균에서 $\pm 2 \mathrm{SD}$ 를 초과하는 경우 가외치 (outlier)로 간주하여 분석에서 제외하였다(Kail \& Salthouse 1994). 그 결과, 분석에서 제외된 반응은 총 $3.45 \%$ 였다. 숫자찾기 과제에서 는 12 개의 보기 숫자목록을 동등하게 4 개의 블록으로 나누어 목 표 숫자가 첫 번째 블록인 앞의 3 개 중에 있을 경우인 $\mathrm{C} 1$, 두 번째 블록에 있을 경우인 $\mathrm{C} 2$, 세 번째 블록에 있을 경우인 $\mathrm{C} 3$, 네 번째 블록에 있을 경우인 C4로 나누어 15문항씩 배치하였는데, C1-C4 조건은 모두 목표자극이 목록에 있는 경우로 4 가지 정확도에 대한 퍼센트 점수와 반응속도의 평균을 산출하였다. 그리고 목표 숫자 가 12 개의 보기 숫자목록에 없는 경우인 NC도 15 문항 배치 하에 해당 조건의 퍼센트 점수와 반응속도를 산출하였다.

또한 각 하위 과제 간 상관관계를 분석하기 위하여 피어슨 적률 상관계수(Pearson product moment correlation coefficients)를 산 출하였다. 그리고 언어능력(수용어휘, 표현어휘)을 얼마나 설명해 줄 수 있는지 살펴보고자 단계적 중다회귀분석(stepwise multiple regression)을 실시하였다. 본 연구의 모든 통계 분석은 SPSS version 19 (SPSS Inc., Chicago, IL, USA)를 사용하였다.

\section{연구결과}

비언어 처리용량 및 처리속도에서의 집단 간 차이 분석 집단 간 매트릭스(matrix) 과제 수행의 차이

비언어 시각 처리용량을 측정하기 위한 매트릭스 과제 수행의 결 과는 Table 2와같다.

정순 조건에서 일반아동 집단의 매트릭스 수행은 63.69\% (SD = 20.1), 단순언어장애 집단의 매트릭스 수행은 $57.78 \%(\mathrm{SD}=21.3)$ 으 로 나타났으며, 집단 $\left(F_{(1,62)}=1.300, p>.05\right)$ 에 따른 집단 간 차이가 유의하지 않았다. 그러나, 역순 조건에서 일반아동 집단의 매트릭 스 수행은 $51.53 \%(\mathrm{SD}=20.6)$, 단순언어장애 집단의 매트릭스 수행 은 $41.78 \%(\mathrm{SD}=17.0)$ 으로 나타났으며 집단 $\left(F_{(1,62)}=4.273, p<.05\right)$ 에 따른 집단 간 차이가 유의하였다. 즉, 일반아동 집단과 단순언어 장애 집단은 매트릭스의 정순 조건에서는 집단 간 차이가 유의하지 않았으나, 역순 조건에서는 집단간 차이가 유의한 것으로 나타났다.

집단 간 시각적 숫자찾기(visual number search) 과제의 정확도 및 반응속도의 차이

비언어 시각 처리정확도 및 처리속도를 측정하기 위한 시각적 숫 
Dongsun Yim, et al. • Nonlinguistic Visual Processing Capacity and Speed

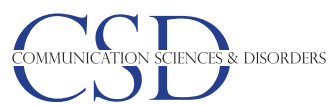

Table 2. Descriptive statistics of matrix performances (\%) by subgroups

\begin{tabular}{lccc}
\hline & NL (N=32) & SLI (N=32) & $F$ \\
\hline Matrix_f & $63.69(20.10)$ & $57.78(21.33)$ & 1.300 \\
Matrix_b & $51.53(20.60)$ & $41.78(16.96)$ & $4.273^{*}$
\end{tabular}

Values are presented as mean (SD).

$\mathrm{NL}=$ normal language children; $S \mathrm{LI}=$ children with specific language impairment; Matrix_F=matrix forward span; Matrix_B= matrix backward span. ${ }^{*} p<.05$.

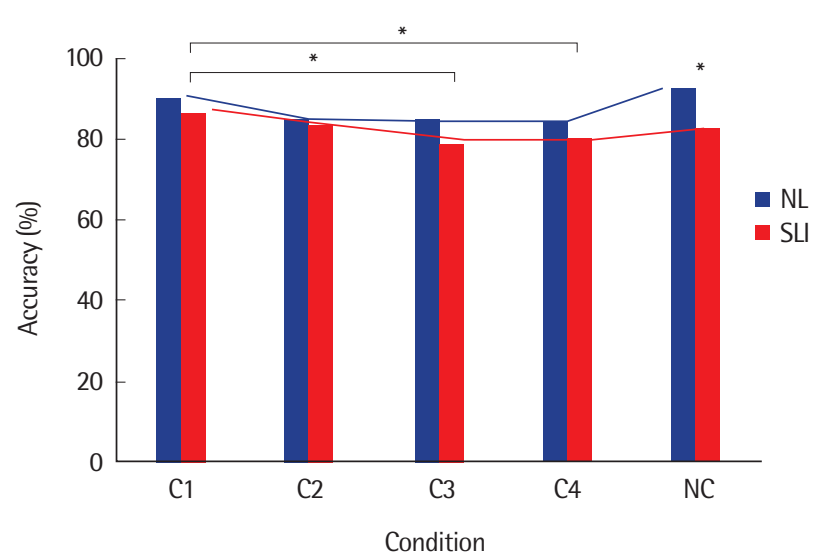

Figure 2. Visual number search accuracy by 5 conditions in children with NL and SLI.

$\mathrm{NL}=$ normal language children; $\mathrm{SL}=$ children with specific language impairment.

자찾기 과제 수행의 결과는 Figures 2, 3과 같다.

먼저, 정확도는 4가지 조건에 따른 집단 간 차이가 통계적으로 유 의하였으며 $\left(F_{(3,186)}=6.512, p<.001\right)$, 이에 따라 Bonferroni 사후분 석을 실시한 결과, 세부적으로는 조건 1 과 3 , 조건 1 과 4 간 유의한 수행차이가 있었다 $(p<.05)$. 또한, 두 집단 간 C1-C4 조건의 평균수 행차이 역시 통계적으로 유의하지 않았으며 $\left(F_{(1.62)}=2.179, p>.05\right)$, 두 집단 간 $\mathrm{C} 5(\mathrm{NC})$ 조건의 수행의 정확도 차이는 통계적으로 유의 하였다 $\left(F_{(1.62)}=8.215, p<.01\right)$. 한편, 조건 및 집단 간 이차상호작용 은 유의하지 않았다 $\left(F_{(4,248)}=1.417, p>.05\right)$.

반응속도는 4 가지 조건에 따른 차이가 통계적으로 유의하였으 며 $\left(F_{(3,186)}=20.857, p<.001\right)$, 이에 따라 Bonferroni 사후분석을 실 시한 결과, 세부적으로는 조건 1 과 2 , 조건 1 과 3 , 조건 1 과 4 간 유의 한 수행차이가 있었다 $(p<.05)$. 두 집단 간 시각적 숫자찾기 과제 수 행의 반응속도 차이 역시 통계적으로 유의하지 않았다 $\left(F_{(1.62)}=1.671\right.$, $p>$.05). 그러나 추가적으로 개별 조건에서 집단 간 차이가 통계적 으로 유의한지 살펴보기 위해 일원분산분석(one-way ANOVA)를 실시한 결과, 조건 1 에서 유의한 차이가 나타났다 $\left(F_{(1.62)}=5.632\right.$, $p<.05)$. 두 집단 간 $\mathrm{C5}(\mathrm{NC})$ 조건의 반응속도의 차이는 통계적으로

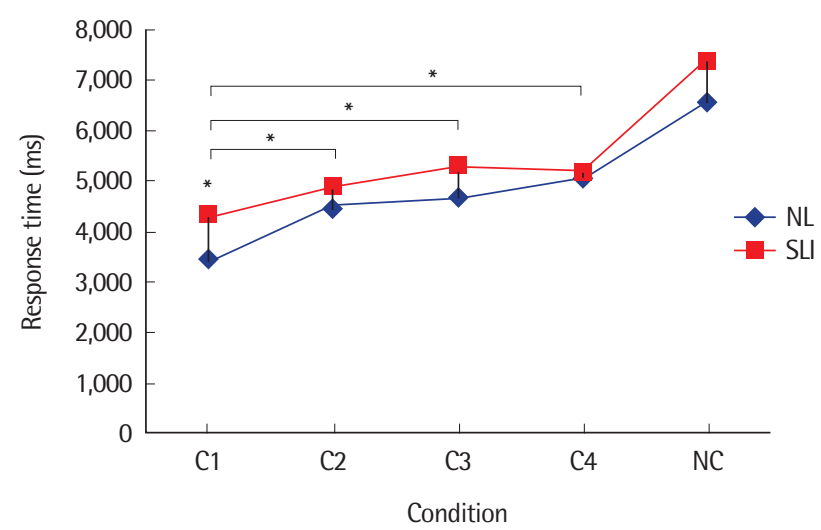

Figure 3. Visual number search response time by 5 conditions in children with $\mathrm{NL}$ and SLI.

$\mathrm{NL}=$ normal language children; $\mathrm{SLI}=$ children with specific language impairment.

유의하지 않았다 $\left(F_{(1.62)}=1.527, p>.05\right)$. 또한, 조건 및 집단 간 이차 상호작용은 유의하지 않았다 $\left(F_{(3,186)}=1.774, p>.05\right)$.

\section{집단별 비언어 처리용량, 처리속도, 그리고 언어능력 간 상관관계}

\section{단순언어장애 집단에서의 각 변인 간 상관관계}

단순언어장애 아동 집단에서 수용어휘력(REVT_R), 표현어휘 력(REVT_E), 비언어 처리용량 2가지(Matrix_f, Matrix_b), 비언어 처리정확도 2가지(VNS_C1C4 C1-C4의 평균, VNS_NC), 비언어 처리속도 2가지(VNS_C1C4 C1-C4의 평균, VNS_NC), 총 8가지 변수 간 유의한 상관관계가 나타나는지 살펴보기 위해 Pearson 적 률상관계수를 산출하였다. 그 결과, 단순언어장애 아동 집단의 수 용 및 표현어휘력과 유의한 상관이 있는 비언어 처리과제 변수는 나타나지 않았다( $p>$.05).

한편, 비언어 처리과제 간 유의한 상관관계를 살펴보았다. Matrix_ $\mathrm{f}$ 는 Matrix_b $(r=.552, p<.05)$, VNS_C1C4_RT $(r=-.489, p<.05)$ 와 유의한 상관이 있었으며, Matrix_b는 VNS_C1C4_RT ( $r=-.366$, $p<.01)$ 와 유의한 상관이 있었다. 즉, 단순언어장애 아동 집단에서 는 비언어 처리정확도 보다는 처리속도가 비언어 처리용량과 일관 적으로 유의한 상관이 있었다. 이에 대한 세부결과를 Table 3에 제 시하였다.

\section{일반아동 집단에서의 각 변인 간 상관관계}

일반아동 집단에서 수용어휘력(REVT_R), 표현어휘력(REVT_ $\mathrm{E})$, 비언어 처리용량 2가지(Matrix_f, Matrix_b), 비언어 처리정확 도 2가지(VNS_C1C4 C1-C4의 평균, VNS_NC), 비언어 처리속도 
Table 3. Correlation matrix in SLI group

\begin{tabular}{|c|c|c|c|c|c|c|c|c|}
\hline & $M(S D)$ & REVT_E & Matrix_f & Matrix_b & VNS_C1C4_Acc & VNS_C1C4_RT & VNS_C5(NC)_Acc & VNS_C5(NC)_RT \\
\hline REVT_R & $52.5(9.14)$ & $.360^{*}$ & -.029 & .188 & .052 & .003 & .077 & -.141 \\
\hline REVT_E & $60.5(11.73)$ & - & .189 & .032 & .129 & .049 & .241 & -.163 \\
\hline Matrix_f & $57.8(21.33)$ & & - & $.552^{*}$ & .137 & $-.489 *$ & .131 & -.338 \\
\hline Matrix_b & $41.8(16.96)$ & & & - & .010 & $-.366^{* *}$ & .014 & -.274 \\
\hline VNS_C1C4_Acc & $86.7(11.11)$ & & & & - & $.373^{*}$ & $.404^{*}$ & $.437^{*}$ \\
\hline VNS_C1C4_RT & $4,915.5(1,883.19)$ & & & & & - & .308 & $.849 * *$ \\
\hline VNS_C5(NC)_Acc & $82.8(15.78)$ & & & & & & - & .210 \\
\hline VNS_C5(NC)_RT & $7,360.6(3,025.20)$ & & & & & & & - \\
\hline
\end{tabular}

$\mathrm{SLI}=$ children with specific language impairment; REVT=Receptive \& Expressive Vocabulary Test (Kim, Hong, Kim, Jang, \& Lee, 2009); REVT_R=receptive vocabulary; REVT_ $\mathrm{E}=$ expressive vocabulary; Matrix_f=matrix forward span; Matrix_b= matrix backward span; VNS=visual number search; $A c c=a c c u r a c y ; R T=r e s p o n s e$ time. ${ }^{*} p<.05,{ }^{* *} p<.01$.

Table 4. Correlation matrix in NL group

\begin{tabular}{|c|c|c|c|c|c|c|c|c|}
\hline & $\mathrm{M}(\mathrm{SD})$ & REVT_E & Matrix_f & Matrix_b & VNS_C1C4_Acc & VNS_C1C4_RT & VNS_C5(NC)_Acc & VNS_C5(NC)_RT \\
\hline REVT_R & $72.5(11.60)$ & $.680^{* *}$ & .277 & $.402^{* *}$ & $.439 *$ & -.057 & .148 & -.042 \\
\hline REVT_E & $78.5(9.81)$ & - & .260 & $.457^{* *}$ & .325 & -.277 & .056 & -.294 \\
\hline Matrix_f & $63.7(20.10)$ & & - & $.696^{* *}$ & $.535^{* *}$ & $-.451^{* *}$ & .340 & -.289 \\
\hline Matrix_b & $51.5(20.60)$ & & & - & $.578^{* *}$ & $-.375^{* *}$ & $.454^{* *}$ & -.325 \\
\hline VNS_C1C4_Acc & $86.5(8.95)$ & & & & - & -.290 & $.370^{*}$ & -.017 \\
\hline VNS_C1C4_RT & $4,408.5(1,174.06)$ & & & & & - & -.345 & $.774^{* *}$ \\
\hline VNS_C5_Acc & $92.4(10.80)$ & & & & & & - & -.297 \\
\hline VNS_C5_RT & $6,575.7(1,937.80)$ & & & & & & & - \\
\hline
\end{tabular}

$\mathrm{NL}=$ normal language children; REVT = Receptive \& Expressive Vocabulary Test (Kim, Hong, Kim, Jang, \& Lee, 2009); REVT_R=receptive vocabulary; REVT_E= expressive vo-

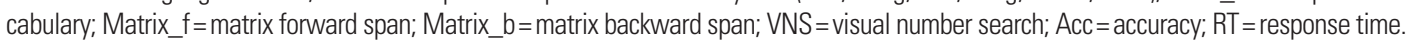
${ }^{*} p<.05,{ }^{* *} p<.01$.

2가지(VNS_C1C4 C1-C4의 평균, VNS_NC), 총 8가지 변수 간 유 의한 상관관계가 나타나는지 살펴보기 위해 Pearson의 적률상관 계수를 산출하였다. 그 결과, 일반아동 집단의 수용어휘력(REVT_ $\mathrm{R})$ 과 Matrix_b $(r=.402, p<.01), \mathrm{VNS} \_\mathrm{ClC} 4 \_\mathrm{ACC}(r=.439, p<.05)$ 가 유의한 상관을 보였으며, 표현어휘력(REVT_E)과 Matrix_b $(r=.457, p<.01)$ 가 유의한 상관을 보였다.

비언어 처리과제 간 유의한 상관관계를 살펴보면, Matrix_f는 Matrix_b $(r=.696, p<.01)$, VNS_C1C4_Acc $(r=.535, p<.01)$, VNS_C1C4_RT $(r=-.451, p<.01)$ 와 유의한 상관이 있었다. Matrix_b는 VNS_C1C4_Acc $(r=.578, p<.01), \mathrm{VNS} \_C 1 C 4 \_\mathrm{RT}(r=$ $-.375, p<.01)$, 그리고 VNS_NC_Acc $(r=.454, p<.01)$ 와 유의한 상 관이 있었다. 이에 대한 세부결과를 Table 4에 제시하였다.

\section{집단별 언어능력(수용어휘력, 표현어휘력)에 대한 비언어 처리능력의 설명력}

단순언어장애 및 또래 일반아동의 언어능력(수용어휘력, 표현어 휘력)을 가장 잘 설명해주는 비언어 처리능력이 존재하는지 살펴
보기 위해 비언어 처리용량 2가지(Matrix_f, Matrix_b), 비언어 처 리정확도 2가지(VNS_C1C4 C1-C4의 평균, VNS_NC), 비언어 처 리속도 2가지(VNS_C1C4 C1-C4의 평균, VNS_NC), 총 6가지를 독립변수로 하여 단계적 중다회귀분석(stepwise multiple regression)을 실시하였다.

그 결과, 단순언어장애 아동 집단에서 언어능력(수용어휘력, 표 현어휘력)을 설명해주는 유의한 비언어 처리능력 요인은 없었다. 반면, 또래 일반아동 집단에서 언어능력(수용어휘력, 표현어휘력) 을 유의하게 설명해주는 요인은 모두 Matrix_b였다. 즉, 수용어휘 력은 Matrix_b가약 $22.3 \%$ 유의하게 설명해줄 수 있었으며 $\left(F_{(1.30)}=\right.$ $8.616, p<.01)$, 표현어휘력은 Matrix_b가 $20.9 \%$ 유의하게 설명해줄 수 있는 것으로 나타났다 $\left(F_{(1.30)}=7.922, p<.01\right)$.

\section{논의 및 결론}

본 연구에서는 단순언어장애 및 또래 일반아동의 비언어 처리용 량 및 처리속도의 차이를 살펴보고, 단순언어장애 및 또래 일반아 
동 집단 각각에서 비언어 처리용량과 처리속도, 그리고 언어능력(수 용어휘력, 표현어휘력)간 유의한 상관관계가 나타나는지를 살펴본 다음, 각 집단 아동의 언어능력을 유의하게 설명해주는 비언어 처 리용량 또는 처리속도 세부 변인은 무엇인지 알아보고자 하였다.

첫째, 단순언어장애 아동은 비언어 처리용량을 측정하는 매트릭 스(matrix) 과제에서 순서대로 기억하는 능력은 또래 일반아동에 비해 부족하지 않았으나, 거꾸로 기억하는 능력은 유의하게 부족한 수행을 보였다. 구어 반응이 요구되지 않는 시공간적 작업기억 과제 인 매트릭스는 표면적으로는 아동들의 언어능력이 개입되지 않는 것처럼 보이지만, 그 기저에서 아동들의 언어능력과 인지능력이 서 로 밀접한 관련을 맺고 있기 때문에 처리능력을 측정하는 언어과제 뿐만 아니라 비언어과제 수행에서도 단순언어장애 아동들의 부족 한 수행이 나타날 수 있다(Fernald \& Marchman, 2012; Kohnert \& Windsor, 2004; Marchman \& Fernald, 2008). 특히, 순서대로 기억 해야 하는 정순과제에 비해 역순으로 기억하는 과제의 조건은 Kail 과 Salthouse (1994)가 언급한 정보처리의 요소 중 공간(space), 즉 '처리용량'의 부담이 상대적으로 더 크게 주어지고, 난이도도 더 높 다고 볼 수 있어 다른 언어과제에 비해 비언어적 과제인 매트릭스가 단순언어장애 아동들의 과제수행 부담을 줄였음에도 불구하고 역 순 과제에서는 이들의 어려움이 드러날 수 있었던 것으로 보인다 (Bishop, 2006; Conti-Ramsden \& Durkin, 2012; Leonard et al., 2007; Thomas et al., 2011).

처리용량과 처리속도가 유기적으로 연결되어있는 시각적 숫자 찾기 수행은 Kail과 Salthouse (1994)가 언급한 공간(space), 시간 (time), 효율성(energe)의 3요소가 총체적으로 관련될 수 있으며, 정 확도와 처리속도를 모두 살펴볼 수 있는 장점을 지닌다. 먼저, 정확 도 측면에서는 두 집단 간 숫자찾기 과제 수행에서 유의한 차이를 보였다. 특히, 단순언어장애 아동 및 또래 일반아동들은 C5(NC) 조건에서 유의한 차이를 보였던 것이 특징이다. 이는 $\mathrm{C} 5(\mathrm{NC})$ 조건 이 목표숫자(target)와 일치하는 항목이 12개의 보기 숫자목록에 서 없음을 판단하고 "X"를 누르는 과정을 포함한다. C1-C4 조건이 모든 12 개의 보기 숫자목록을 검토하지 않고도 목표숫자(target) 와 일치하는 항목이 보이는 즉시 "O"를 눌러 수행할 수 있었던 것 에 비해, 모든 12 개의 보기 숫자목록을 검토한 끝에 판단해야 하는 C5(NC) 조건은 C1-C4 조건과 과제수행에 요구되는 처리능력에 비 해 그 부담이 더 높을 수 있다. 반응속도 측면에서는, 두 집단 간 과 제수행의 반응속도 차이는 유의하지 않았으나, 세부적으로는 $\mathrm{Cl}$ 조건에서 유의한 차이를 보였다. 이는 목표숫자(target)와 가깝게 배치될수록 반응속도는 빠를 것으로 기대되고, 멀리 배치되면 느 릴 것으로 기대되는데 또래 일반아동이 빠르게 반응하는 만큼 단
순언어장애 아동들이 빠르게 반응하지는 못한 것으로 보인다. 이 는 처리과제 수행에서의 유의하게 느린 처리속도가 아동의 언어문 제를 잘 예측해줄 수 있어 이것이 단순언어장애 아동을 설명해주 는 하나의 요인일 수 있음을 보고한 선행연구를 일부 뒷받침해줄 수 있다(Park et al., 2015). 특히, 반응속도와 관련해서 목표 숫자와 멀리 배치된 C4에 비해 목표 숫자와 가깝게 배치되어 쉽게 일치항 목을 찾아낼 수 있는 $\mathrm{C} 1$ 에서 집단 간 차이가 더욱 크게 나타난 본 연구의 결과를 통해 두 집단의 수행 차를 명확하게 확인하기 위해 지나치게 높은 과제 부담을 줄 필요는 없으며, 오히려 비교적 쉬운 과제 조건에서의 느린 반응속도가 아동의 언어문제로 인한 과제수 행의 제한을 예측하는 데 더 높은 기여를 할 수 있을 것으로 보인다.

둘째, 단순언어장애 아동 집단에서는 수용 및 표현어휘력과 유 의한 상관이 있고 설명력을 가지는 비언어 처리과제 변수는 나타나 지 않았으나, 또래 일반아동 집단에서는 수용어휘력과 Matrix_b, VNS_C1C4_ACC가 유의한 상관을 보였으며, 표현어휘력과 Matrix_b가 유의한 상관을 보였다. 단순언어장애 아동의 어휘력에 대 해 어떤 처리용량 및 처리속도 요인도 유의한 상관을 보이지 않고 설명력을 지닌 요인도 없었던 것을 통해 이들의 어휘능력과 처리능 력이 충분히 긴밀한 연결고리를 이루고 있지 않음을 추론해볼 수 있다. 반면, 또래 일반아동 집단의 수용 및 표현어휘력을 모두 설명 해주는 공통 요인으로 Matrix_b가 있었는데, 이 과제가 시공간적 작업기억을 측정하는 비언어적 과제임에도 불구하고 언어능력의 주요 하위 요인 중 하나인 어휘력에 일관적으로 기여하는 부분이 존재한다는 것을 확인할 수 있다. 이는 어휘를 포함한 언어능력이 독립적이기보다는 다양한 인지, 운동영역들과 함께 발달하고 서로 유기적으로 연결되어 있어서 영역 간 도움을 주고받을 수 있을 때 더욱 언어발달에 도움이 되는 것으로 보인다. 한편, 일반아동의 숫 자찾기 과제에서 $\mathrm{ClC} 4$ 조건의 정확도는 수용어휘력과 상관이 있 었는데, 아동이 어떤 어휘에 대한 개념을 정확히 인지하고 이해할 때 목표자극과 일치하는 항목의 빠르고 정확한 처리가 서로 밀접 한 관련성을 가질 수 있다. 이미 18-30개월부터 아동들의 처리 효율 성과 어휘력의 관계는 긴밀하게 나타날수록 어휘가 큰 폭으로 증가 하는 반면, 처리 효율성이 낮을수록 말(speech) 처리 효율성 역시 낮아 추후 아동기 및 성인기가 될 때까지 언어학습과 언어능숙도 에 미치는 영향은 매우 크다고 볼 수 있다(Fernald \& Marchman, 2012). 따라서 아동들의 어휘력 증진과 추후 전 생애적인 언어학습 능력 및 언어능숙도를 위해 전반적인 처리 효율성을 높여주는 것 이 필요할 수 있다.

본 연구의 제한점으로는 본 연구의 대상이 만 5-8세로 취학 전부 터 학령기에 이르기까지 연령의 폭이 넓어 본 연구결과에 연령에 
따른 발달적 변수가 세심하게 고려되지 못했다는 것이다. 취학 전 후로 급격한 언어 및 인지적인 발달이 이루어짐을 고려해볼 때 후 속연구에서는 본 연구의 대상이었던 5-8세 아동보다 더 어린 유아 (만 3-4세), 취학 직전의 아동(만 5-6세), 초기 학령기(만 7-8세)의 아동들을 연령대별로 나누어 살펴본다면 본 연구보다 더욱 명확한 결과를 얻을 수 있을 것이다. 그뿐만 아니라 현재 단순언어장애 범 주에 속하면서도 언어문제를 해결할 수 있는 가능성이 있는 아동, 또는 현재 일반아동 범주에 속하면서도 위험군(at risk) 아동으로 분류될 수 있는 가운데 처리능력, 특히 처리용량과 처리속도의 기 여도의 양상을 살펴보고 그에 대한 심도 있는 논의가 이루어진다면 임상현장에서도 유용한 시사점으로 남을 수 있을 것으로 보인다.

\section{REFERENCES}

Bayliss, D. M., Jarrold, C., Baddeley, A. D., Gunn, D. M., \& Leigh, E. (2005). Mapping the developmental constraints on working memory span performance. Developmental Psychology, 41, 579-597.

Bishop, D. V. (2006). What causes specific language impairment in children? Current Directions in Psychological Science, 15, 217-221.

Campbell, T., Dollaghan, C., Needleman, H., \& Janosky, J. (1997). Reducing bias in language assessment: processing-dependent measures. Journal of Speech, Language, and Hearing Research, 40, 519-525.

Conti-Ramsden, G., \& Durkin, K. (2012). Language development and assessment in the preschool period. Neuropsychology Review, 22, 384-401.

Fernald, A., \& Marchman, V. A. (2012). Individual differences in lexical processing at 18 months predict vocabulary growth in typically developing and late-talking toddlers. Child Development, 83, 203-222.

Fernald, A., Perfors, A., \& Marchman, V. A. (2006). Picking up speed in understanding: Speech processing efficiency and vocabulary growth across the 2nd year. Developmental Psychology, 42, 98-116.

Hood, M., \& Conlon, E. (2004). Visual and auditory temporal processing and early reading development. Dyslexia, 10, 234-252.

Johnston, J. R., \& Ellis Weismer, S. (1983). Mental rotation abilities in languagedisordered children. Journal of Speech, Language, and Hearing Research, 26, 397-403.

Kail, R. (1986). Sources of age differences in speed of processing. Child Development, 57, 969-987.

Kail, R., \& Salthouse, T. A. (1994). Processing speed as a mental capacity. Acta Psychologica, 86, 199-225.

Kail, R., Pellegrino, J., \& Carter, P. (1980). Developmental changes in mental rotation. Journal of Experimental Child Psychology, 29, 102-116.

Keum, B. R., Kim, Y. T., \& Lee, E. J. (2010). Nonlinguistic performance in Korean children with specific language impairments. Korean Journal of Communication \& Disorders, 15, 592-602.

Kim, Y. T., Hong, G. H., Kim, K. H., Jang, H. S., \& Lee, J. Y. (2009). Receptive \& expressive vocabulary test (REVT). Seoul: Seoul Community Rehabilitation Center.

Kohnert, K., \& Windsor, J. (2004). The search for common ground. Part II. Nonlinguistic performance by linguistically diverse learners. Journal of Speech, Language, and Hearing Research, 47, 891-903.

Lahey, M., Edwards, J., \& Munson, B. (2001). Is processing speed related to severity of language impairment? Journal of Speech, Language, and Hearing Research, 44, 1354-1361.

Leonard, L. B. (1998). Children with specific language impairment. Cambridge, MA: MIT Press.

Leonard, L. B., Weismer, S. E., Miller, C. A., Francis, D. J., Tomblin, J. B., \& Kail, R. V. (2007). Speed of processing, working memory, and language impairment in children. Journal of Speech, Language, and Hearing Research, 50, 408-428.

Marchman, V. A., \& Fernald, A. (2008). Speed of word recognition and vocabulary knowledge in infancy predict cognitive and language outcomes in later childhood. Developmental Science, 11, F9-F16.

Miller, C. A., Kail, R., Leonard, L. B., \& Tomblin, J. B. (2001). Speed of processing in children with specific language impairment. Journal of Speech, Language, and Hearing Research, 44, 416-433.

Miller, L. T., \& Vernon, P. A. (1996). Intelligence, reaction time, and working memory in 4-to 6-year-old children. Intelligence, 22, 155-190.

Moon, S. B., \& Byun, C. J. (2003). Korean Kaufman assessment battery for children (K-ABC). Seoul: Hakjisa.

Newbury, J., Klee, T., Stokes, S. F., \& Moran, C. (2016). Interrelationships between working memory, processing speed, and language development in the age range 2-4 years. Journal of Speech, Language, and Hearing Research, 59, 1146-1158.

Park, J., Mainela-Arnold, E., \& Miller, C. A. (2015). Information processing speed as a predictor of IQ in children with and without specific language impairment in grades 3 and 8. Journal of Communication Disorders, 53, 57-69.

Pisoni, D., Kronenberger, W., Roman, A., \& Geers, A. (2011). Measures of digit span and verbal rehearsal speed in deaf children following more than 10 years of cochlear implantation. Ear and Hearing, 32, 60s-74s. 
Poll, G. H., Miller, C. A., Mainela-Arnold, E., Adams, K. D., Misra, M., \& Park, J. S. (2013). Effects of children's working memory capacity and processing speed on their sentence imitation performance. International Journal of Language \& Communication Disorders, 48, 329-342.

Shanahan, M. A., Pennington, B. F., Yerys, B. E., Scott, A., Boada, R., Willcutt, E. G., ... \& DeFries, J. C. (2006). Processing speed deficits in attention deficit/hyperactivity disorder and reading disability. Journal of Abnormal Child Psychology, 34, 584.

Thomas, E., Reeve, R., Fredrickson, A., \& Maruff, P. (2011). Spatial memory and executive functions in children. Child Neuropsychology, 17, 599-615.

Weber-Fox, C., Spruill, J., Fick, W., Hampton, A., Cochran, E., Leonard, L., \& Tomblin, B. (2005). Linguistic and non-linguistic auditory processing in adolescents with specific language impairment (SLI): an ERP study. Poster presented at the Annual Meeting of the Cognitive Neuroscience Society, New York, NY.

Windsor, J., Kohnert, K., Loxtercamp, A. L., \& Kan, P. F. (2008). Performance on nonlinguistic visual tasks by children with language impairment. Ap- plied Psycholinguistics, 29, 237-268.

Wright, B. A., Bowen, R. W., \& Zecker, S. G. (2000). Nonlinguistic perceptual deficits associated with reading and language disorders. Current Opinion in Neurobiology, 10, 482-486.

Yim, D., Kim, S. Y., \& Yang, Y. (2015). Factor analysis of working memory tasks based on information processing characteristics: predictive factors of receptive vocabulary and quick incidental learning in children with typically developing and receptive vocabulary delay. Communication Sciences \& Disorders, 20, 304-318.

Yim, D., Yang, Y., \& Kim, S. (2015). Domain-specific working memory performance in children with and without specific language impairment. Communication Sciences \& Disorders, 20, 13-23.

Yim, D., Yang, Y., Jo, Y., Lee, J., \& Seong, J. (2015). Grammatical meta-linguistic awareness and executive functioning skills in preschool-age children with and without specific language impairment. Journal of Speech \& Hearing Disorders, 24, 345-359. 


\section{국문초록}

\section{단순언어장애 아동의 비언어 정보 처리용량, 처리속도 그리고 어휘능력 간의 관계 \\ 임동선 · 양윤희 \\ 이화여자대학교 언어병리학과}

배경 및 목적: 본 연구에서는 선행 언어지식과 능력이 과제 수행에 미치는 영향을 최소화할 수 있는 비언어 정보 처리과제 수행을 통하 여 단순언어장애 아동들의 언어능력 결핍을 일반인지처리 이론으로 설명하고 비언어 처리용량 및 처리속도, 그리고 어휘력의 관계가 단순언어장애 및 일반아동들에게서 어떻게 나타나는지 살펴보고자 하였다. 방법: 만 4-8세의 단순언어장애 아동 32 명, 그리고 이들의 생활연령을 일치시킨 또래 일반아동 32 명, 총 64 명이 본 연구에 참여하였다. 아동들의 비언어 정보 처리용량을 측정하기 위해 시공간적 작업기억 과제인 매트릭스(matrix), 비언어 처리속도를 측정하기 위해 시각적 숫자찾기 과제(visual number search)를 실시하였다. 결 과: 단순언어장애 아동은 또래 일반아동에 비해 비언어 정보 처리용량 과제인 매트릭스 수행에서 정순 과제(Matrix_f)에서는 부족하 지 않았으나, 역순 과제(Matrix_b)에서는 유의하게 낮은 수행을 보였다. 또한, 일반아동 집단에서는 어휘능력과 비언어 정보 처리(Matrix_b, VNS_C1C4_ACC)가 유의한 상관을 보였으나, 단순언어장애 아동 집단에서는 어휘능력과 비언어 정보 처리능력 간 유의한 상 관이 나타나지 않았다. 논의 및 결론: 일반아동 집단에서는 비언어 정보 처리능력과 어휘능력의 관계가 유의하였으나, 단순언어장애 아동에게서는 비언어 정보 처리능력과 어휘능력 간 관계가 견고하지 않아 이들의 비언어 정보 처리능력 또한 언어능력 증진을 위해 효 율적으로 사용될 수 있도록 다양한 기회를 제공하는 것이 유용할 수 있다.

핵심어: 비언어 시각 과제, 처리용량, 처리속도, 단순언어장애 아동

\section{참고문헌}

금보람, 김영태, 이은주(2010). 학령 전 단순언어장애 아동과 일반아동의 시. 청지각과제 수행능력 비교. 언어청각장애연구, 15, 592-602.

김영태, 홍경훈, 김경희, 장혜성, 이주연(2009). 수용·표현어휘력검사(REVT). 서울: 서울장애인종합복지관.

문수백, 변창진(2003). K-ABC 교육·심리측정도구(Korean-Kaufman assessment battery for children). 서울: 학지사.

임동선, 김신영, 양윤희(2015). 정보처리 특성에 따른 작업기억 과제의 탐색적 요인분석: 일반아동 및 수용어휘지체 아동의 수용어휘력 및 빠른우연

학습 예측요인. 언어청각장애연구, 20, 304-318.

임동선, 양윤희, 김신영(2015). 단순언어장애 아동과 일반 아동의 작업기억 제시방식 및 과제유형에 따른 수행능력 비교. 언어청각장애연구, 20, 1323.

임동선, 양윤희, 조연주, 이지연, 성지민(2015). 학령전기 단순언어장애 및 일반아동의 문법성 메타언어인식과 집행기능 수행능력 비교분석. 언어치료

연구, 24, 345-359. 